\title{
THE GREEK PHILOLOGICAL SOCIETY IN CONSTANTINOPLE
}

\author{
BY PETER CHARANIS \\ Dr. Charanis is Voorhees Professor of History \\ at Rutgers University
}

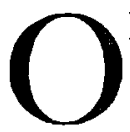

N March 3, I 86I, prominent Greeks of Constantinople met and talked about the establishment of a learned society. A month later they decided to do so, and on May 4 they proclaimed by a celebration its foundation. Thus was born the Greek Philological Society of Constantinople (Hellenikos Philologikos Syllogos Konstantinoupoleos), which, in time became the principal intellectual and educational force among the Greeks-and they numbered millions-living in the Ottoman empire. It lasted until 1922 when, as the result of historical developments, the Greeks fled Turkey. The Society disintegrated and was subsequently officially abolished by the Turkish State. Its library holdings were dispersed among various Turkish learned societies.

The Society stated as its primary function the examination of philological subjects. The term "philological" has in the original Greek meaning a much wider significance than it does in English. It includes in fact anything that has a scientific or scholarly basis and which is conveyed to others by the word. As a consequence the subjects periodically discussed by the Society covered a wide range. They included anything from literature and language to commerce and archaeology - in brief, the whole intellectual realm. This in time made the Society a strong general educational force, promoting the investigation of various themes by offering prizes, and establishing and maintaining schools. Counted among its active members at various times were some of the outstanding scholars of Europe.

From the very beginning it was decided that the Society should keep a record of its proceedings and that it should publish in extenso or in part the learned papers read at its various meetings. A periodical for this purpose was, therefore, established. The first volume appeared in 1863 ; the last, volume thirty-three, in I914. Included 
in the contents of these volumes are the minutes of the sessions of the Society; the resources at its disposal; the prizes it offered and the awards it made; records of the establishment and maintenance of schools, and more importantly, the learned papers read at its various sessions. These last include in their coverage literature, education, economics, philosophy, history, archaeology, not all necessarily related to Greek history and civilization. I was struck, for instance, by a paper on slavery in the United States, which appeared in volume two ( 1864 ).

The periodical of the Society, thirty-three volumes altogether, constitutes a precious collection. Precious because it is an invaluable source for the study of the intellectual climate of the Ottoman capital during the second half of the nineteenth century; but precious also for the scholarly papers that it contains. Some of these papers, particularly those dealing with archaeology are irreplaceable, irreplaceable not only because of the quality of their scholarship but also because monuments which they describe or inscriptions they make public no longer exist. The collection is very rare, and the Rutgers University Library has been fortunate to obtain a set. To be sure the set is not complete - it lacks the last three volumes-but every effort is being made to complete it. The language of the periodical is, of course, Greek. 